\title{
ACCOUNTING, ANALYSIS AND AUDITING OF INFORMATION REGARDING TANGIBLE ASSETS IN THE ROMANIAN ECONOMIC ENTITIES
}

\author{
Luminița Rus ${ }^{1}$, \\ Mărioara Beleneși ${ }^{2}$, \\ Dana Simona Gherai ${ }^{3}$
}

\begin{abstract}
Unlike the companies who are incorporated with the purpose of obtaining profit, the non-profit organizations and public institutions are functioning based on various sources of funding. The present work aims at the recognition in the accounts of the fixed assets amounted to those three types of entities. In this process we have started to study the accounting rules applicable to these entities, as well as specialized works of recent date. The aspects studied and presented with regard to the definition, initial evaluation and subsequent evaluation were followed by a comparison of their types for the entities subject to study, and then present a comparative statement of recording in the accounts of major operations relating to the fixed assets. Finally, we present some information regarding the indicators of financial and economic analysis that uses the value of the fixed assets and some aspects which are examined by the auditor in his objective opinion regarding the tangible assets. It may be noted that tangible assets occupies an important place in the life of an entity and that the reflection of them in their accounting provides the same information, even though the accounting formulas used are different. But what makes the difference in accounting is closely related to the specific of the economic entity analyzed and the information they must submit to users of accounting information.
\end{abstract} accounting

Keywords: tangible assets, fixed assets, non-current assets, rules of evaluation, principles of

JEL Code: $M 41$

\section{Introduction}

Different from the companies, the non-profit organizations and the public institutions are functioning as economic entities which fulfill their role through the financing of their activity. Although they can achieve revenue, obtaining the economic profit is not their principal goal.

Because they are more commonly known - in terms of organizing and management of accounting - the companies will constitute a basis for comparison in this study. We want to focus on the accounting of non-profit organizations and public institutions, which, although numerous, raises questions when we encounter economic operations which are identical with those of companies.

In this study we will analyze the tangible asset - or fixed assets - starting from defining, setting forth the rules of evaluation and then their recording in accounting, as information on their accounting, completing with the analysis and control of the existence and evaluation of the fixed assets for the purpose of providing useful information to those interested in the entity.

\footnotetext{
${ }^{1}$ University of Oradea, Oradea, Romania, Email: 1rus@uoradea.ro

${ }^{2}$ University of Oradea, Oradea, Romania, Email: mimibelenesi@yahoo.com

${ }^{3}$ University of Oradea, Oradea, Romania, Email: dgherai@ uoradea.ro
} 


\section{Methodology of Research}

Our study is based on the knowledge of specific accounting rules for the economic entities analyzed - companies, non-profit organization and public institutions - using for this purpose the law in this area, as well as the literature of the time.

The objective of this study is to recognize correctly in the accounting of the economic entity of the operations relating to tangible asset regardless the type of the economic entity which have them in possession.

In order to achieve this objective we examined regulatory accounting rules specific to those economic entities and we studied the literature to address issues related to: the definition of fixed assets, the initial assessment and subsequent evaluation in the accounts of the entity's economic heritage, the accounts used and the information which they present in the economic entity. After fixing the concepts used, we proceeded to identify the differences and similarities regarding these issues.

\section{Literature Review}

Tangible assets constitute an important subject for the users of accounting information which resulted in the fact that professionals and researchers in accounting would document and then, the information collected should be described in the specialty-books or articles.

Mention in this respect the effort of authors Maria Berheci (2010) and Ionel Jianu (2012) which treats the problem of evaluation in accounting, Liliana Feleagă and Niculae Feleagă (2007) and Dumitru Matiș (2010) addressing issues of recognition of fixed assets in accounting in compliance with accounting principles.

The author Virginia Greuceanu-Cocoș (2014) brings together information of the accounting and the law regarding the organizations without patrimonial purpose providing a number of accounting monograph useful in the accounting of fixed assets.

We note the work of authors Alberta Gisberto, Ileana Nișulescu, Cleopatra Șendroiu (2012), Marinela-Daniela Manea (2012) and Virginia Greuceanu-Cocoș (2014) who treated in their books the subject of accounting of public institutions, from the problem of presenting the concepts and legislation applicable and completing by giving examples of operations related to activity of the public institutions.

\section{Definitions and Concepts}

Fixed assets-for companies and non-profit legal entities-or tangible assets for public institutions are those assets which are intended to serve the economic entity in its activities for a period longer than one year. In this regard, we present a comparison of their definition by grouping the information on the three types of entities subject to this study (table no.1).

Table 1

The definition of fixed assets

\begin{tabular}{|l|l|c|}
\hline \multicolumn{1}{|c|}{$\begin{array}{c}\text { Economic } \\
\text { entity type }\end{array}$} & \multicolumn{1}{|c|}{ The definition of fixed assets } & $\begin{array}{c}\text { Presentation in } \\
\text { the balance } \\
\text { sheet }\end{array}$ \\
\hline $\begin{array}{l}\text { Companies } \\
\text { (OMFP } \\
1802 / 2014)\end{array}$ & $\begin{array}{l}\text { Active generators of future economic benefits and kept for } \\
\text { a period greater than one year (art. 138) } \\
\text { Recognition of assets as being fixed or current assets shall } \\
\text { depend on the purpose for which they are intended and the } \\
\text { intention of keeping. (art.135 alin (1)) }\end{array}$ & $\begin{array}{l}\text { Tangible assets } \\
\text { in the category } \\
\text { of }\end{array}$ \\
\cline { 1 - 2 } $\begin{array}{l}\text { Organizations } \\
\text { without } \\
\text { patrimonial }\end{array}$ & $\begin{array}{l}\text { Assets intended for use on a continuous basis in order to } \\
\text { carry out the activity (art 25) } \\
\text { Recognition of assets as being fixed or current assets shall }\end{array}$ & \multicolumn{1}{|c|}{ Fixed assets } \\
\hline
\end{tabular}




\begin{tabular}{|l|l|c|}
\hline $\begin{array}{l}\text { purpose } \\
\text { (OMFP } \\
1969 / 2007)\end{array}$ & depend on the purpose for which they are intended. (art.24) \\
\hline $\begin{array}{l}\text { Public } \\
\text { institution } \\
\text { (OMFP } \\
1917 / 2005)\end{array}$ & $\begin{array}{l}\text { Assets held for use in the long term (cap.III. secț.A art.1) } \\
\text { meet all the established value provided by the Government } \\
\text { and the normal duration of use greater than one year (cap. }\end{array}$ & $\begin{array}{c}\text { Active fixe în } \\
\text { categoria } \\
\text { Activelor } \\
\text { necurente }\end{array}$ \\
\hline
\end{tabular}

Source: own processing according to the legislation

Note that in all three cases the tangible assets -or named fixed-represent assets held by the economic entity in order to use them in its activities, fulfilling the condition of minimum value set by the Government, today 2,500 lei.

In addition, differentiation in accounting in the category of fixed or stock-inventory itemsdepends on the destination and the intention to preserve them.

Similarities and differences in the accounting treatment of tangible and intangible assets exist from the point of view of their depreciation. Depreciation represents the systematic allocation of the amount of fixed assets in the cost during the period determined for the use of an active or on the number of units of production or services expected to be achieved by the use of the asset, using the depreciation methods under the laws in force.

The recording in accounting of the depreciation represent depreciation expense of the fixed assets corresponding to the depreciation recorded and not of the diminishing value of assets used, beginning with the month following its entry in activity.

In terms of accounting, the depreciation methods that can be used by the entity are:

- For companies: straight-line depreciation, declining-balance depreciation, accelerated depreciation calculated per unit of product or service (OMFP 1802/2014, art.240)

- For organizations without patrimonial purpose: only straight-line depreciation for those used for economic purpose (OMFP 1969/2007 art.89 alin.1) and methods used for companies of those used in economic activities (OMFP 1969/2007 art.89 alin.2)

- For public institutions: just straight-line method of depreciation (OMFP 1917/2005, Cap. III, art. 1.1.5.)

For all three types of entities, the land does not depreciate. In the case of public institutions, beside lands, the following tangible assets are non-depreciable (OG 81/2003 art.9):

- goods belonging to the public domain of the state and to the administrative-territorial units according to the law, including the investments made in these;

- tangible fixed assets of public services of local interest activities which conducts activities of an economic nature, whose physical and moral depreciation shall be recovered through tariff or price, according to the law;

- tangible fixed assets contained in the preservation, as well as the reserves which are recorded in the accounts as tangible fixed assets;

- lakes, ponds, and bogs, which are not are the result of investments;

- national cultural heritage assets;

- goods used under a lease agreement;

- goods of the nature of weapons and combat technology.

In terms of fiscal view, the depreciable fixed asset represent tangible asset that meet all the conditions for the possession and use of these assets, the duration of use greater than one year and the fiscal value equal to or greater than the limit set by the Government (Law 227/2015 art.28).

Beside land already mentioned, there are not subject to depreciation: paintings and works of art, lakes, ponds and bogs that have not been the subject of investment, goods of public domain 
financed from budgetary sources, dwellings of the protocol, any fixed assets which are not losing their value during their use, etc.

The methods of depreciation permissible in terms of fiscal view are:

- straight-line depreciation for all fixed assets;

- declining-balance depreciation for all fixed assets, except buildings;

- accelerated depreciation only for technological equipment, machine-tools and working facilities, computers and office equipment.

\section{Evaluation of Fixed Assets}

The evaluation represents the method of determination of the value of recording in the accounts of the elements presented in the annual financial statements, the value determined in accordance with accounting principles prescribed by the accounting regulations.

Regarding the evaluation, it should be reflected in the accounts the "link between cost and value, starting from the premise that the price recorded on the occasion of a transaction on a market, it is the expression of a value, or vice versa, that the value of a good is the basis of its price" (Feleagă \& Feleagă, 2007, page.303)

The book value at which the fixed assets are presented in the balance sheet is the historic cost value reduced by the depreciation recorded and the adjustments for accumulated depreciation up to that time (Greuceanu-Cocoș, 2014, page. 47)

For tangible asset to be presented at their fair value, the evaluation and their recognition in the accounts should be made respecting several principles of accounting. For better comparison we made a summary of the accounting principles laid down by the accounting regulations applicable to the entities subject to this study (table no. 2).

Accounting principles applicable to the entities reviewed

\begin{tabular}{|c|c|c|c|}
\hline $\begin{array}{l}\text { The principle laid down by } \\
\text { the accounting regulations }\end{array}$ & Companies & Non-profit Organization & $\begin{array}{c}\text { Public } \\
\text { Institutions }\end{array}$ \\
\hline Business continuity & \multirow{7}{*}{ Yes } & \multirow{7}{*}{ Yes } & \multirow{7}{*}{ Yes } \\
\hline Consistent methods & & & \\
\hline Prudence & & & \\
\hline $\begin{array}{l}\text { Accrual (independence of the } \\
\text { accounting year) }\end{array}$ & & & \\
\hline Intangibility & & & \\
\hline $\begin{array}{l}\text { Separate evaluation of assets } \\
\text { and liabilities }\end{array}$ & & & \\
\hline Non-compensation & & & \\
\hline $\begin{array}{l}\text { Evaluation at the cost of } \\
\text { acquisition or cost of } \\
\text { production }\end{array}$ & Yes & Rule of evaluation & Yes \\
\hline Materiality threshold & Yes & $\begin{array}{l}\text { Information presented in } \\
\text { the notes to the financial } \\
\text { statements }\end{array}$ & Materiality \\
\hline Comparability of information & $\begin{array}{l}\text { Qualitative } \\
\text { requirements }\end{array}$ & $\begin{array}{l}\text { Unmentioned in the } \\
\text { category of principles, but } \\
\text { the requirement is set } \\
\text { forth in the notes on the } \\
\text { accounts }\end{array}$ & Yes \\
\hline $\begin{array}{l}\text { The prevalence of economic } \\
\text { over the judiciary (reality over }\end{array}$ & $\begin{array}{l}\text { Mentioned in the } \\
\text { previous }\end{array}$ & Unmentioned & Yes \\
\hline
\end{tabular}




\begin{tabular}{|l|c|l|l|}
\hline appearance) & $\begin{array}{c}\text { regulations OMFP } \\
1802 / 2014\end{array}$ & & \\
\hline
\end{tabular}

Source: own processing according to the legislation

Analyzing the information, we note a number of common accounting principles applicable to all three categories of entities examined and one principle for public institutions, but unmentioned for the other two categories. Two common principles to companies and public institutions represent for the non-profit organizations the rule of evaluation or information presented in the notes to the annual financial statements.

The comparability of the information laid down as a principle to be respected for public institutions constitutes a qualitative requirement of accounting information for companies, while non-profit organizations for the lack of comparability of the information must be presented in the notes to the annual financial statements.

In compliance with accounting principles, the valuation rules of the fixed assets are provided for four major moments in their life:

- $\quad$ at the entrance to the entity (table no. 3);

- $\quad$ subsequent to the entry into, through the process of reassessment (table no. 4);

- at inventory and at the date of the financial statements, at book value, while respecting the principle of prudence culminated in the recognition of the value of adjustments of fixed assets;

- at the moment of exit from the entity, the historical cost, simultaneously with the withdrawal of amortizations or depreciations-adjustments.

Table 3

Valuation at the date the entity

\begin{tabular}{|l|c|c|c|}
\hline \multicolumn{1}{|c|}{ Method of entry into entity } & Companies & $\begin{array}{c}\text { Non-profit } \\
\text { Organization }\end{array}$ & $\begin{array}{c}\text { Public } \\
\text { Institutions }\end{array}$ \\
\hline $\begin{array}{l}\text { Acquisition, acquired for valuable } \\
\text { consideration }\end{array}$ & \multicolumn{3}{|c|}{ Cost of acquisition } \\
\hline The products of entity & \multicolumn{3}{|c|}{ Cost of production } \\
\hline Contribution to capital & \multicolumn{3}{|c|}{ The value of consideration } \\
\hline Received free of charge & \multicolumn{2}{|c|}{ The fair market value } \\
\hline
\end{tabular}

Source: own processing according to the legislation

It should be noted that the rules of evaluation at the date of the entry in the entity are the same for all three types of entities, with the exception of capital shares, which are not there for public institutions because the contributions of the state or administrative territorial units are represented by funds, patrimonial result and reserves, non-retrievable in the element of Social capital.

Table 4

Evaluation in the process of reassessment

\begin{tabular}{|c|c|c|c|}
\hline Aspects analyzed & Companies & $\begin{array}{c}\text { Non-profit } \\
\text { Organization }\end{array}$ & $\begin{array}{c}\text { Public } \\
\text { Institutions }\end{array}$ \\
\hline Asset evaluations & $\begin{array}{c}\text { Fair market value, determined by reviewers, with the } \\
\text { reflection of results of revaluation in accounts }\end{array}$ \\
\hline Depreciation & $\begin{array}{c}\text { Depreciation is recorded with effect from the next fiscal } \\
\text { year }\end{array}$ \\
\hline $\begin{array}{c}\text { Fully depreciated } \\
\text { fixed assets }\end{array}$ & $\begin{array}{c}\text { Permitted for fully depreciated fixed asset and, settling a } \\
\text { new period of life of the asset }\end{array}$ \\
\hline
\end{tabular}




\begin{tabular}{|c|c|}
\hline $\begin{array}{c}\text { Posting in general } \\
\text { ledger }\end{array}$ & $\begin{array}{c}\text { Gross value method, by recalculating the gross value and } \\
\text { the recorded depreciation }\end{array}$ \\
\cline { 2 - 2 } & Net value method by removing the adjustments recorded \\
\hline
\end{tabular}

Source: own processing according to the legislation

We note that the rules for the evaluation of fixed assets at the date of reassessment shall be the same for all three types of economic entities subject to study.

Note that the reevaluation must be done on a regular basis to ensure that the accounting value thus determined will not differ too much from what would be determined by using fair value at the date of preparation of the financial statements. (Jianu, 2012, page. 75)

It is important to remember that apart from the revaluation process, there are other subsequent events of the registration in the accounts of the fixed assets that may affect their value. Making expenditures that represent modernization of fixed assets will generate additional benefits for the entity which will increase their value, while the repairs carried out in order to regain or maintain their capacity to generate benefits will be recognized as expenses of the period found in the profit and loss account. (Manea, 2012, page. 74)

\section{Accounting of Fixed Assets}

The accounting recognition indicates the fact generator of assets, debts, own capitals, revenue and expenditure in the economic entity, specify the criteria what underlies their registration in the accounts and then reported in the annual financial statements (Matiș, 2010, page.144).

In Romania, the financial accounting is based on the use of a chart of accounts, which by the symbols used facilitates the recording of operations concerning the items in the balance sheet and the profit and loss account. For the entities subject to this study, the accounting regulations foresee the use of charts of accounts.

Legal entities without patrimonial purpose, although intended for the performance of nonprofit activities, can carry out economic activities generating profits. In this sense, accounting regulations applicable to them, include a chart of accounts structured by the type of activity, thus the accounts for fixed assets, detailing is presented analytical for non-profit-making activities and economic activities (Deaconu, 2012, page. 132).

Although different in all three chart of accounts regarding the tangible assets are included in class 2-also called tangible assets accounts, or fixed assets accounts. We are syntheses the main operations relating to fixed assets, without mentioning the value added tax, bearing in mind that entities subject to this study may not be registered as TVA payers, in which case the amount of the TVA included in the invoice becomes an element of the purchase price (table no. 5).

Table 5

Main operations relating to tangible assets

\begin{tabular}{|c|c|c|c|c|}
\hline \multirow[b]{2}{*}{$\begin{array}{l}\text { Economic operation } \\
\text { relating to the } \\
\text { tangible assets }\end{array}$} & \multirow[b]{2}{*}{ Companies } & \multirow[b]{2}{*}{$\begin{array}{l}\text { Non-profit } \\
\text { Organization }\end{array}$} & \multicolumn{2}{|c|}{ Public Institution } \\
\hline & & & $\begin{array}{l}\text { Depreciable } \\
\text { Fixed Assets }\end{array}$ & $\begin{array}{c}\text { Non- } \\
\text { depreciable } \\
\text { Fixed Assets }\end{array}$ \\
\hline $\begin{array}{l}\text { Contribution to } \\
\text { capital }\end{array}$ & $21 x=456$ & $21 x=101$ & - & - \\
\hline Purchase & $21 x=404$ & $21 x=404$ & $21 x=404$ & $\begin{array}{c}21 x=10 x \text { şi } \\
682 x=404\end{array}$ \\
\hline $\begin{array}{l}\text { Received through } \\
\text { donation }\end{array}$ & $21 x=4753$ & $21 x=133$ & $21 x=779$ & - \\
\hline Plus of inventory & $21 x=4754$ & $21 x=134$ & $21 x=779$ & - \\
\hline Acquisition in & $21 x=167$ & $21 x=167$ & $21 x=167$ & $21 \mathrm{x}=10 \mathrm{x}$ și \\
\hline
\end{tabular}




\begin{tabular}{|l|l|c|c|c|}
\hline financial leasing & & & $682 \mathrm{x}=167$ \\
\hline Own-produced & $21 \mathrm{x}=231,722$ & $21 \mathrm{x}=231,739$ & $21 \mathrm{x}=231,722$ & - \\
\hline $\begin{array}{l}\text { Revaluation }(\mathrm{no} \\
\text { indication here of } \\
\begin{array}{l}\text { accumulated } \\
\text { depreciation) }\end{array}\end{array}$ & $\begin{array}{c}21 \mathrm{x}=755,105 \\
\mathrm{sau}\end{array}$ & $\begin{array}{c}21 \mathrm{x}=105 \\
\mathrm{sau} \\
105=21 \mathrm{x}\end{array}$ & $\begin{array}{c}21 \mathrm{x}=105 \mathrm{x} \\
\mathrm{sau} \\
105 \mathrm{x}=21 \mathrm{x}\end{array}$ & $\begin{array}{c}21 \mathrm{x}=105 \mathrm{x} \mathrm{sau} \\
105 \mathrm{x}=21 \mathrm{x}\end{array}$ \\
\hline Sale & $461=7583$ & $461=738,7583$ & $461=791$ & $461=791$ \\
\hline $\begin{array}{l}\text { Removal of obsolete } \\
\text { tangible fixed assets }\end{array}$ & $\begin{array}{l}\% \mathrm{x}=21 \mathrm{x} \\
6583\end{array}$ & $\begin{array}{l}\%=21 \mathrm{x} \\
28 \mathrm{x} \\
6583\end{array}$ & $\begin{array}{l}\% 91 \\
281 \mathrm{x}\end{array}$ & $10 \mathrm{x}=21 \mathrm{x}$ \\
\hline
\end{tabular}

Source: own processing according to the legislation

Observe the multitude of differences in recognition in accounting of the operations relating to tangible assets, but also that there are some transactions for which accounting formula is the same in all three cases of the entities studied.

You should note that where it finds differences in accounting, which makes the difference in accounting formulas is closely related to the specific of the economic entity analyzed. For example,

- in the case of public institutions: depreciable fixed assets or fixed assets nondepreciable;

- in the case of non-profit organizations: non-profit activity or economic activity.

It should be noted, however, that whatever the formula used for the different accounting operations relating to tangible assets-or fixed assets - the accounting information offered by the accounts of class 2 are the same because regarding to the economic content there are fixed assets or noncurrent active - and regarding the accounting function there are debit accounts (Bogdan, 2013, pag. 247).

Fixed assets accounts begin functioning by being debited with the beginning balance, are debited with the increase in value of fixed assets -through purchase, donation, contribution, plus of inventory, own production, reevaluation, are credited with diminishing the value of fixed assets -by sale, donation, destruction, minus of the inventory balance-and has a debit ending balance which offers information about the value of the fixed assets contained at the end of the period.

\section{Economic and Financial Analysis of the Economic Entity Using Fixed Assets}

The investments represent an important chapter in the life of each economic entity. Purchase of fixed assets-by acquisition, production, donations and other ways-with the aim of carrying out the objects of the economic entity in obtaining subsequent advantages represents what we call "investment" (Berheci, 2010, pag. 519).

Delimitation of the term investment from the term equiped through the achizition of the fixed assets depends on the technology used by the entity. Equipping the entity with tangible assets and the dynamic providing necessary technology can be verified by the users of accounting information through calculation of the indicators:

$\checkmark \quad$ Degree of technical Endowment calculated with the formula

$$
G I T=\frac{V M M F}{N M S},
$$

where $\mathrm{VMMF}=$ average value of fixed assets

NMS = average number of employees,

Underlines the degree of substitution between capital and labor (Robu, Anghel și Șerban, 2014, pag. 172)

Fixed asset entrie coefficient, calculated according to the formula

$$
\mathbf{k}=\mathbf{I M} / \mathbf{M f}
$$


where $\mathrm{IM}=$ fixed asset entries

$\mathrm{Mf}=$ total fixed assets

highlights the effort of entity to keep up with the technical progress (Popa și Meșter, 2006, pag. 147)

$\checkmark \quad$ The index of the fixed assets installed, calculated according to the formula

$$
\text { ipi }=\frac{\text { nI }}{n E x} \times 100
$$

where $\mathrm{nI}=$ number of fixed assets entered

$\mathrm{nEx}=$ number of existing fixed assets,

reflecting the degree of use of fixed assets, the normal situation being that the value of the index is $\leq 100$ (Popa și Meșter, 2006, pag. 150)

$\checkmark \quad$ The index of the intensive use, calculated according to the formula

where $\mathrm{Q}=$ the volume of production

$$
\text { Iui }=\frac{\mathbf{Q}}{\mathrm{C} \times \mathrm{T}},
$$

$\mathrm{C}=$ capacity of fixed assets

$\mathrm{T}=$ the operating time of the fixed assets (Popa și Meșter, 2006, pag. 155)

means the production obtained by an asset in a certain time fraim reflecting the efficiency of the use of fixed assets.

From the information and indicators of economic and financial analysis which are using fixed assets value we mention:

$\checkmark \quad$ Rotational speed of fixed assets, calculated by formula

where $\mathrm{CA}=$ revenue

$$
\mathrm{VRIC}=\mathrm{CA} / \mathrm{IC}
$$

$\mathrm{IC}=$ tangible assets,

expressing the effectiveness of the management of fixed assets

$\checkmark \quad$ Financial Working Capital calculated with the formula

$$
\text { FRF }=\text { CPM }- \text { AIN, }
$$

where $\mathrm{CPM}=$ permanent capital

$\mathrm{AIN}=$ net fixed assets,

offers information on financing needs and the sources from which they can be covered, and there are three situations (Burja, 2009, pag. 239):

- $\mathrm{CPM}>\mathrm{AIN}$ - financing of a portion of current assets is submitted on behalf of the permanent capital;

- CPM < AIN - expresses a state of financial imbalance of the economic entity

- $\mathrm{CPM}=\mathrm{AIN}$ - reflect a financial balance, but risky from the point of view of the entity's liquidity

$\checkmark \quad$ Own Working Capital calculated with the formula

where $\mathrm{Kpr}=$ equity

$$
\text { FRP }=\text { Kpr }- \text { AIN, }
$$

AIN = net fixed assets (Burja, 2009, pag. 241)

it provides information on the financial autonomy of the entity 
We must mention that the accounting regulations do not make it mandatory for the presentation on the annual financial statements of the components of the calculation of the indicators mentioned, only in the administrator's report - or explanatory notes where appropriate of the relevant information for the activities of the entity, among others, and those about the assets.

\section{Auditing of the Information on Fixed Assets}

We know that the audit represent the activity whereby independently, through the procedures and rules of inspection, the auditor will examine the suitability and the manner of operation of the entity's economic actions and expressed his view by reference to the applicable standards (Feleagă \& Feleagă, 2007, pag 153).

„The purpose of an audit is to enhance the degree of confidence of intended users in the financial statements. This is achieved by the expression of an opinion by the auditor on whether the financial statements are prepared, in all material respects, in accordance with an applicable financial reporting framework. In the case of most general purpose frameworks, that opinion is on whether the financial statements are presented fairly, in all material respects, or give a true and fair view in accordance with the framework" (ISA200:72).

Therefore, auditing financial statements represents the most used method by the auditor, because it provide him fair and reasonable information useful in expressing an opinion.

The auditor, in performing his duties, shall use procedures and audit techniques to justify and verify the usefulness and the quality of the accounting information (Dănescu, 2007, pag.53).

With regard to the fixed assets, the auditor shall examine the conformity of the information recorded in the primary documents with the economic operations of the tangible assets. In this respect, he will examine at least:

- invoices and records of reception and placing in service of the entries;

- documents used to justify the output;

- documentation on the re-evaluation;

- documents made in the ocasion of inventory;

- record documents: sheet asset, fixed assets register;

- elaboration of a plan of depreciation and amortization expenses.

After examining the documents, the collection and interpretation of the audit, the auditor shall express an opinion about the reflection of fixed assets in the financial statements according to the applicable reporting framework of the entity.

\section{Conclusions}

Fixed assets, through their role of generating additional benefits, occupies an important place in the life of the economic entity. To ensure the quality of the accounting information concerning fixed assets it requires knowledge of the accounting rules on their recognition in accounting, based on accounting principles.

Starting from the definition of concepts and definition of fixed assets, through the reference to the rules of evaluation required by the accounting regulations and their comparison in the case of the three types of entities -companies, non-profit organizations and public institutions - we have identified the differences and similarities with regard to the basic rules in evaluating fixed assets.

As a result of this study we conclude the following:

- with regard to the accounting of tangible assets: there are operations to which the accounting formula is the same for all types of entities, but there are plenty of differences that can be attributed to the specific requirements of the entities analyzed;

- with regard to the analysis of information about the tangible asset : at least seven recommended indicators for which we presented the formulas for their calculation although there is no obligation of presentation of their calculation in the financial 
statements - they can offer support to users of accounting information in their decisionmaking;

- with regard to the auditing of information on tangible assets: the auditor will examine the supporting documents of economic operations relating to fixed assets, but also their situation - through the operational documents or inventory.

\section{Bibliography}

1. *** Legea nr. 227/2015 privind Codul fiscal publicată în Monitorul Oficial, Partea I, nr. 688 din 10 septembrie 2015, cu modificările și completările ulterioare.

2. *** OG 81/2003 privind reevaluarea și amortizarea activelor fixe aflate în patrimoniul instituțiilor publice, publicată în Monitorul Oficial nr. 624 din 31 august 2003.

3. *** OMFP 1802 din 29 decembrie 2014 pentru aprobarea Reglementărilor contabile privind situațiile financiare anuale individuale și situațiile financiare anuale consolidate publicat în Monitorul Oficial, Partea I, nr. 963 din 30 decembrie 2014.

4. *** OMFP 1917 din 12 decembrie 2005 pentru aprobarea Normelor metodologice privind organizarea și conducerea contabilității instituțiilor publice, Planul de conturi pentru instituțiile publice și instrucțiunile de aplicare a acestuia, punlicat în Monitorul Oficial, Partea I, nr. 1186 și 1186bis din 29 decembrie 2005, cu modificările și completările ulterioare.

5. *** OMFP 1969 din 09 noiembrie 2007 privind aprobarea reglementărilor contabile pentru persoanele juridice fără scop patrimonial publicat în Monitorul Oficial, Partea I, nt. 846 din 10 decembrie 2007.

6. *** OMFP 2021 din 17 decembrie 2013 pentru modificarea și completarea Normelor metodologice privind organizarea și conducerea contabilităţii instituţiilor publice, Planul de conturi pentru instituțiile publice și instrucțiunile de aplicare a acestuia, aprobate prin Ordinul ministrului finanțelor publice nr. 1917/2005, publicat în Monitorul Oficial, Partea I, nr. 831 și 831bis din 24 decembrie 2013.

7. Berheci Maria, 2010. Valorificarea raportărilor financiare. Sinteze contabile: teorie, analize, studii de caz,Edutura CECCAR, București.

8. Bogdan Victoria (coordonator), Scorțe Carmen Mihaela, Balaciu Diana Elisabeta, Beleneși Mărioara, 2013. Bazele contabilității. Repere teoretice și aspecte practice, Editura Universității din Oradea, Oradea.

9. Burja Camelia, 2009. Analiză economico-financiară, Aspecte metodologice și aplicații practice, Editura Casa Cărții de Știință, Cluj-Napoca.

10. Dănescu Tatiana, 2007. Audit financiar. Convergențe între teorie și practică, Editura Irecson, București.

11. Deaconu Sorin-Constantin, 2012. Particularități ale contabilității entităților, Editura C.H. Beck, București.

12. Feleagă Liliana, Feleagă Niculae, 2007. Contabilitate financiară. O abordare europeană și internațională. Ediția a doua. Volumul 1. Contabilitate financiară fundamentală, Editura Economică, București.

13. Greuceanu-Cocoș Virginia, 2014. Contabilitatea în partidă dublă și legislația persoanelor juridice fără scop patrimonial, simplificată și actualizată, Editura Universitară, București.

14. http://www.ifac.org/system/files/downloads/a008-2010-iaasb-handbook-isa-200.pdf .

15. Jianu Ionel, 2012. Evaluarea în contabilitate. Teorie și metodă, Editura Economică, București.

16. Manea Marinela-Daniela, 2012. Contabilitatea instituţiilor publice. Ediţia a II-a, Editura C.H. Beck, București.

17. Matiş Dumitru, 2010. Bazele contabilităţii. Fundamente și premise pentru un raționament profesional autentic, Editura Casa Cărții de Știință, Cluj-Napoca.

18. Popa (Lezeu) Dorina, Meșter Cornelia, 2006. Analiză economico-financiară: elemente teoretice și aplicații practice, Editura Universității din Oradea, Oradea. 
19. Robu Vasile, Anghel Ion, Șerban Elena-Claudia, 2014. Analiza economico-financiară a firmei, Editura Economică. 